\title{
Sociale dialoog: verleden, heden en toekomst
}

Valeria Pulignano (CESO - KU Leuven)

\section{Sociale dialoog in de naoorlogse periode}

In de naoorlogse periode hebben nationale overheden vaak hun toevlucht genomen tot tripartiete overeenkomsten met sociale partners, omdat zij de steun nodig hadden van de grote vakbonden wier invloed groter en doorslaggevender werd. Ondanks de relatief lage syndicalisatiegraad in de zuidelijke landen van de EU (zoals Italië en Frankrijk) in vergelijking met de Scandinavische (zoals Denemarken) en de continentale landen (zoals België), hebben ook hier het antagonistische karakter van de arbeidsverhoudingen en het sterke mobilisatievermogen van de vakbonden een belangrijke rol gespeeld in het garanderen van steun en compromis. Toch bleef het naoorlogse sociale compromis om drie hoofdredenen fundamenteel ambigu en instabiel. In de eerste plaats was het sociale compromis een weerspiegeling van een specifiek historisch gegroeid evenwicht tussen klassenverhoudingen, die voor het grootste deel alleen voor de 'geavanceerde' economieën gold. Ten tweede bood de sociale dialoog, ondanks de verschillende verschijningsvormen per land, in alle gevallen een compromis tussen de nationale arbeidersbewegingen, de werkgevers die vooral nationaal opereren als het om bedrijfseigendom en productiestrategieën gaat, en de overheden die in grote mate autonoom hun sociale en economische beleid bepalen: een resultaat van het begrensde karakter van economische internationalisering. Ten slotte beteugelde het bestaan van een alternatief sociaaleconomisch model in Oost-Europa - hoe geperverteerd en repressief dan ook - de kapitalistische agressie tot op zekere hoogte.

\section{Sociale dialoog nu}

De voorwaarden die het naoorlogse sociale compromis vergezelden en in stand hielden zijn vandaag de dag niet meer aan de orde. Dit heeft te maken met verschillende aanjagers van transformatie. Ten eerste heeft de globalisering - waarvan de Europese economische eenwording een belangrijk element is - de dominante kapitalistische (handels-)agglomeraties buiten de nationale invloedssfeer geduwd. Er zijn veel verschillende manieren om de historische ontwikkeling van de globalisering te conceptualiseren, met inbegrip van de technologische fundamenten en geografische reikwijdte. Wij willen hier vooral de veranderingen in haar basisdynamiek uitlichten. Haar vroegste verschijningsvorm draaide om internationale goederenstromen: ruwe materialen, nijverheidsproducten, maar ook arbeid. Het midden van de $20 \mathrm{e}$ eeuw zag een kwalitatieve verschuiving richting een doorslaggevende (dominante) rol van multinationals en de ontwikkeling van wat nog het best globale meerwaardeketens genoemd kunnen worden, die door bedrijfsstrategen worden gebruikt om de eigenlijke producenten te onderwerpen aan een voortdurende druk tot kostenverlaging, vrij verkeer van werknemers en een grotere banenconcurrentie op de interne Europese markt. Aan de andere kant brengt de opkomst van een globale platformeconomie nieuwe uitdagingen met zich mee. Ze legt immers een nieuwe 'dominante wereldorde' op waarin transacties via online platforms worden afgehandeld en waarin individuele microaanbieders - en niet langer multinationals - een cruciale rol spelen bij het bedienen van klanten over de hele wereld (Lehdonvirta et al., 2018). De financialisering moet als tweede belangrijke verandering genoemd worden. De liberalisering van de financiële markten heeft een reeks financiële producten voortgebracht, zoals hedge funds, private equity, leveraged buyouts, 
kredietderivaten, et cetera. Het is nu mogelijk, en zelfs effectiever, om overschot te genereren zonder waardeproductie: geldelijk gewin kan worden behaald zonder goederen te produceren in de traditionele zin. Bedrijven zijn zelf getransformeerd in handelswaren of goederen die steeds vaker gekocht en verkocht worden. Deze nieuwe waardebron brengt ook weer nieuwe vormen van onzekerheid met zich mee: voor steeds meer werknemers (en hun vakbonden), is het zelfs niet langer duidelijk wie eigenlijk de werkgever is. Ten derde is er de herconfiguratie van de rol van de staat. Het naoorlogse compromis betrok de staat op verschillende manieren. In het bijzonder maar niet uitsluitend in Europa, schiep wetgeving een web van individuele arbeidsrechten, die bovendien de vertegenwoordiging van werknemersbelangen door vakbonden en ondernemingsraden bevorderde. Deze redenering begon en eindigde bij de welvaartsstaat. Door macro-economische reguleringen op Keynesiaanse leest werd een bijna volledige werkgelegenheid gehandhaafd. Overheden werden zelf de belangrijkste werkgevers, zich in de regel inspannend voor goede arbeidsomstandigheden. In de laatste decennia is de neoliberale globalisering echter een alibi geworden voor nationale overheden om antisociale beleidsmaatregelen door te voeren, waarbij benadrukt wordt dat onderwerping aan de internationale markt de enige optie is. We zien dus steeds vaker dat overheden binnen het beleidsdomein van de EU hun toevlucht nemen tot unilateralisme. De beleidsmaatregelen van nationale overheden hebben zich gericht op het terugdringen van de rol van de overheid ('rolling back the state') en het beperken van de sociale bescherming wanneer dat gerechtvaardigd wordt om redenen van productiviteit en concurrentie. In meer of mindere mate hebben alle nationale overheden in Europa hun financiële begrotingen aangepast en een beleid van begrotingsconsolidatie doorgevoerd, met een beperking van de sociale uitgaven en publieke werkgelegenheid (Vaughan-Whitehead, 2013). Deze verschuiving vond bovendien in een relatief kort tijdsbestek plaats, onder druk van de internationale financiële markten en instellingen. Al met al is als gevolg van een gebrek aan middelen en een strakke hervormingsplanning de mogelijkheid op een vruchtbare sociale dialoog en politieke uitwisseling afgenomen.

\section{De toekomst van de sociale dialoog?}

De transitie naar een digitale en groene economie impliceert vergelijkbare uitdagingen voor alle EU-landen. Daartoe behoren ingrijpende industriële veranderingen, de ontwikkeling van nieuwe energiepatronen en technologische verschuivingen, de opkomst van nieuwe bedrijfsmodellen en meer circulariteit in productie en consumptie.

Op veel manieren zal deze transitie positieve effecten genereren. Onze werkomstandigheden en luchtkwaliteit zullen verbeteren. De afhankelijkheid van energie zal afnemen en het kan een belangrijk vehikel blijken in het scheppen van banen, alsook een kans om de knowhow, innovatie en technologische mogelijkheden in Europa te versterken. Om dit economisch potentieel volledig te kunnen benutten zijn een stabiel beleid en investeringsklimaat nodig. Dit is zeker de eerste toegevoegde waarde die beleidsplanning werknemers kan bieden: een grotere zekerheid ten aanzien van het beleidskader en de investering die de hoofdvoorwaarden vormen voor een koers richting een koolstofarme en digitale economie, met behoud en creatie van kwaliteitsjobs in alle sectoren, waaronder de fabrieksnijverheid.

Vanuit het oogpunt van de werknemer betekent de transitie een fundamentele hervorming van de arbeidsmarkt die zowel nieuwe risico's als nieuwe kansen met zich meebrengt: nieuwe arbeidsplaatsen maar ook, in sommige gevallen, het verdwijnen van arbeidsplaatsen (en bedrijven), het vervangen van bestaande beroepen door nieuwe, naast een nood aan nieuwe competenties en vaardigheden. Sommige sectoren en regio's kunnen daar meer negatieve 
invloed van ondervinden dan andere. Het anticiperen op deze tendensen en hun impact op werknemers en bedrijven is de drijvende kracht achter de activiteiten van vakbond- en werkgeversorganisaties. Het klimaatbeleid bijvoorbeeld, en de daarmee gepaard gaande beleidsplanning, biedt vakbonden de mogelijkheid hun kennis van de huidige ontwikkelingen en hun invloed op het klimaatbeleid te vergroten.

Om een 'rechtvaardige transitie' van de beroepsbevolking en de creatie van degelijke en kwalitatief hoogstaande arbeidsplaatsen zeker te stellen. Dat vakbonden en werkgevers aan de governance van de beleidsplanning deelnemen, is daarom bijzonder van belang. De preambule van het Verdrag van Parijs inzake klimaatverandering nodigt partijen uit om 'rekening te houden met de verplichting tot een rechtvaardige transitie van de beroepsbevolking', waarvoor werknemersparticipatie een vanzelfsprekende voorwaarde is. De richtlijnen van de ILO 'voor een rechtvaardige transitie richting ecologisch duurzame en digitale economieën en samenlevingen voor iedereen' bevelen over het algemeen overleg en samenwerking aan tussen werkgevers- en vakbondsorganisaties bij de uitwerking en invoering van beleidsmaatregelen op 'alle mogelijke niveaus en tijdpunten'. Dit onderstreept het belang van de rol van de sociale partners en de sociale dialoog. 